\title{
Production Scheduling and Corporate Productivity Performance in the Nigerian Manufacturing Industry
}

\author{
${ }^{1}$ G.I. Umoh, ${ }^{2}$ Ify Harcourt Wokocha, \\ ${ }^{I}$ Management Department, Faculty of Management Sciences, University of Port Harcourt, Choba, Port \\ Harcourt. Nigeria. \\ ${ }^{2}$ Office Technology and Management, School of Management Sciences, Rivers State College of Arts and \\ Science, Rumuola, Port Harcourt. Nigeria.
}

\begin{abstract}
Operations and production managers have for long identified that production scheduling affects Corporate Productivity Performance of firms in the manufacturing industry. Studies on the influence of production scheduling mechanisms on firms' performance often overlook the possibility of it being taken for granted by managers in the course of manufacturing. This paper investigates the extent to which Production Scheduling, had affected the Corporate Productivity Performance of the Nigerian manufacturing industry. In this respect Corporate Productivity Performance is measured in the areas of cost minimization, enhanced equity capital and growth. Three hypotheses were formulated and questionnaire were distributed to eighty respondents in the eighty sampled manufacturing firms from the one hundred in the industry, quoted in the Stock Exchange(Fact Book 2009). Sixty two copies of the questionnaire were retrieved. These with the financial statements of the firms were used for the analysis. From its findings, the study revealed that production scheduling truly has insignificant impacts on Corporate Productivity Performance of Nigerian manufacturing industry. This finding implies that production Scheduling did not significantly affect the Corporate Productivity Performance of firms. Based on these, the study recommends among others, that the Nigerian manufacturing industry should totally be overhauled, especially in the areas of scheduling, in order to realign and restore the industry from total collapse.
\end{abstract}

Keywords: Production Scheduling, Corporate Productivity Performance.

\section{Introduction}

Production is a process or procedure developed to transform a set of inputs like men, materials, capital, information and energy into a specified set of output like finished products and services in proper quantity and quality, thus achieving the objectives of an enterprise' (Vollman et al, 2007; and Jain and Aggarwal, 2008). The production system likewise is the design process by which elements are transformed into useful products. A process then is an organized procedure for accomplishing the conversion of inputs into output. It is assumed that production can be effective if an appropriate and efficient Production Scheduling $(\boldsymbol{P S})$ technique is in place.

It is the understanding, design and application of this technique that form the focal concept of this research in the Nigerian manufacturing sector. If the manufacturing sector of the Nigerian economy is seriously declining in its contribution to $\boldsymbol{G D P}$, then there is probably the problem of understanding, design and application of $\boldsymbol{P S}$ in the Nigerian economy-especially in the real sector where manufacturing is predominant. This research has looked at existing models and techniques such as linear programming and other mathematical programming techniques, to find out if they are applied anywhere in the industries under study. The study also sought to establish how suitable such models must have been in the context of the Nigerian economy. It is argued that the existing models could not have been developed with the Nigerian economy in mind, or that our economy lacks proper understanding of such models, thereby being unable to adapt it for application in the Nigerian situation.

Despite the rich natural, human and capital resources in the environment, the Nigerian manufacturing sector and indeed the economy is recording a high level of de-industrialization (Eke, 1985; Eleanya, 2002, 2009; Green, 2006). This situation seems to sow the seed for more violent political and social instability. This is because the level of unemployed but employable citizens has continued to: (1) increase exponentially; (2) create a large reserve army of recruitable political thugs and gangsters capable of short changing citizens electorally; (3) generate large number of militants, armed robbers, kidnappers and criminals who will make life nasty, short and brutish for citizens; (4) help to accelerate state failure; and (5) embark on the revolutionary reorganization and reordering of society (Eleanya 2009). He went further to state that stable European and American states have industries which provide a platform for the citizens to be gainfully employed and usefully engaged hence removing a large segment of the population from, hunger, want, poverty, penury, anger and thus the possibility of being available for recruitment as political thugs, miscreants and possibly instigators of political, economic 
and social instability and ultimately, revolution. If other economies of Europe, America and Asia have developed a robust $\boldsymbol{P S}$ mechanisms that could enhance business organizational goals- in the form of corporate productivity performance $(\boldsymbol{C P P})$ of cost minimization, profit maximization, enhanced equity capital and growth,- then there is no excuse whatsoever that Nigeria can give for not accomplishing same with her existing human and economic resources (Jain and Aggarwal, 2008; and Eleanya 2009).

Production Scheduling (PS) is the fitting of specific jobs into a general time table so that orders may be manufactured in accordance with contracted liability or in mass production, so that each component may arrive at and enter to assembly in the order and at the time required (Winston, 2004; Winston and Albright, 2007; Jain and Aggarwal, 2008). Accordingly, the highest efficiency in production is obtained by manufacturing the required quantity of product, of the required quality, at the required time by the best and cheapest method. This explains the current trend of Lean Manufacturing and Just-in-Time production management concepts. (Bestwick and Lockyer, 2008; Johnson and Montgomery 2009; Wild, 2008; Lockyer, 2009). To attain this objective, management employs $\boldsymbol{P S}$ as a tool to coordinate and enhance the performance of all manufacturing activities.

Research evidence in Eleanya 2009 has shown that in Singapore, South Korea, Indonesia, Thailand and Malaysia the manufacturing sector contribution to Gross Domestic Product (GDP) is well over sixty percent $(60 \%)$. According to him, these are countries that have through massive industrialization joined the class of world industrialized nations. Indeed, China whose independence is about eleven (11) years older than Nigeria has a manufacturing share of $\boldsymbol{G D P}$ which is as high as eighty percent $(80 \%)$. As at today, he asserts that manufacturing sector's contribution to $\boldsymbol{G D P}$ in Nigeria is less than three percent (3\%). This is a problem.

There is therefore need to collectively sustain the pressure and advocacy for friendly business environment, stable macro-economic policies, consistent, clear and focused industrial strategy that will provide support and incentive for manufacturing activities, ensure value addition and job creation, to give the economy the required organizational productivity performance of profit maximization/cost minimization, and growth in general.

Thinking along the reasoning of Fowge (1997), it is our belief that interest in $\boldsymbol{P S}$ and corporate productivity performance has spurred curiosity beyond the capacity of scholars to keep pace with it either theoretically or methodologically. This seems to us to be the case in Nigeria as we do not find sufficient evidence of empirical studies on $\boldsymbol{P S}$ and its impact on $\boldsymbol{C P P}$ in the Nigerian Manufacturing Industry. Correspondingly empirical studies on $\boldsymbol{P S}$ and $\boldsymbol{C P P}$ specific-research in Nigeria are scanty (Chinweizu, 1979; Agbadudu, 1996) although Chase et al (2001) while acknowledging that the models of $\boldsymbol{P S}$ and $\boldsymbol{C P P}$ have been developed and tested in western countries, advocates that there is a need for more systematic research to determine whether these models apply elsewhere. It is upon this premise that this study sets out to examine the impact of $\boldsymbol{P S}$ on $\boldsymbol{C P P}$ in the Nigerian Manufacturing Industry with a view to enhancing organizational effectiveness and competitive advantage.

\section{Theoretical Foundation.}

Two key variables were focussed upon in this study, namely, the Criterion Variable - $\boldsymbol{C P P}$ and the Predictor Variable - $\boldsymbol{P S}$. We defined $\boldsymbol{C P P}$ as measured by cost minimization, enhanced equity capital and growth. In the same way, $\boldsymbol{P S}$ has its dimensions of production scheduling. It was assumed that the practice of $\boldsymbol{P S}$ will trigger $\boldsymbol{C P P}$ through its dimensional effects on cost minimization, enhanced equity capital and growth.

The objectives and the research questions for the study were drawn from the hypothesized relationships between the predictor and criterion variables. The conceptual framework assumes a straight line relationship between the predictor variable and the criterion variables. The conceptual framework, which is unidirectional, indicates that $\boldsymbol{C P P}$ is a function of $\boldsymbol{P S}$. This is represented in the following mathematical model:

$\boldsymbol{C P P}=f(\boldsymbol{P S})$ Where:

$$
\begin{aligned}
& \boldsymbol{C P P}=\text { Corporate Productivity Performance } \\
& \boldsymbol{P S}=\text { Production Scheduling. }
\end{aligned}
$$

From the conceptual framework, $\boldsymbol{C P P}$ is measured by the level of cost minimization, enhanced equity capital and growth. The framework also shows the dimension of $\boldsymbol{P S}$ as production scheduling. Consequently our mathematical model can be expanded thus:

$$
\begin{array}{cl}
\boldsymbol{C P P}=f(\mathrm{~s}) & \\
& \text { Where: } \\
& \mathrm{s}=\text { scheduling }
\end{array}
$$

III. Methodology.

The cross sectional survey design is considered most appropriate because what is being investigated is experiences (Anwuluorah, 1987). Again the range of issues and inter-relations are numerous and diverse. The 
study is also a causal study that is intended to identify the effect of the application of $\boldsymbol{P S}$ on $\boldsymbol{C P P}$ in the manufacturing industry. The design is expected to reveal the relationship between $\boldsymbol{P S}$ and $\boldsymbol{C P P}$. The purpose of a cross-sectional survey therefore is to generate a body of data in connection with two or more variables, and to examine and identify patterns of association (Nachimias, and Nachimias, 1981). This design meets our purpose and enables us to generalize from the result of our sample for the entire population. Furthermore, the causal investigation is adopted in this study and is built around the purpose of hypothesis testing in which we examined the causal relationship between $\boldsymbol{P S}$ and $\boldsymbol{C P P}$ in a non-contrived setting.

\subsection{Population of the Study}

The population consists of those manufacturing companies quoted in the Nigerian Stock Exchange (NSE) fact book of 2009. A total of one hundred (100) manufacturing companies were identified, but a sample of eighty (80) was drawn for the study using stratified random sampling method. In this case, the proportional allocation approach was used firstly to determine the number of companies in each stratum (sector) as classified by the Nigerian Stock Exchange (NSE) Factbook of 2009. Thereafter a simple random sampling technique was used to select members of the sample frame from each stratum (sector).

\subsection{Data Collection Methods}

Primary and secondary sources of data collection were explored for this study. The primary data were gathered through the administration of questionnaire designed using Five-Point Likert-Scale. While the secondary data were sourced from the companys' financial statements as reported in the Nigerian Stock Exchange Factbook of 2009.

The structured questionnaire containing questions relating to $\boldsymbol{P S}$ with dimension such as production scheduling, as it affects $\boldsymbol{C P P}$ of firms in the Nigerian manufacturing industry were served on chief executives or senior managers in the production and operations department. The copies of the questionnaire were administered personally and online (where applicable) by the researcher to the respondents. Sixty two (62) copies of the questionnaire were retrieved and analyzed.

To generate the qualitative data, we adopted an in-depth personal interview through the use of open ended questions designed to clarify certain issues and obtain further intricate details about the phenomena under investigation which were difficult to capture through the structured questionnaire. Sometimes, since the interviews were conducted after copies of the questionnaire with their responses had been retrieved, the interview was also used as a confirmatory test of some of the responses especially those that were not clear.

We observed the operations in the study units. Here, we adopted the socio-technical systems model (Susman and Evered, 1978). In this respect, the system's framework guided the collection of facts so that they were organized into an integrated whole about boundaries, transformation of inputs into outputs and the climate of the operations environment. Secondary data were generated from textbooks, journals, company bulletins, annual reports of firms and professional bodies. These materials were reviewed to obtain relevant information about each organization and the phenomena we were studying.

\subsection{Research Hypotheses}

In undertaking this study, we were guided by the following hypotheses:

$\mathbf{H o}_{1}$ There is no significant relationship between production scheduling and cost minimization in the Nigerian Manufacturing Industry.

$\mathrm{Ho}_{2}$ There is no significant relationship between production scheduling and enhanced equity capital in the Nigerian Manufacturing Industry.

$\mathrm{Ho}_{3}$ There is no significant relationship between production scheduling and growth in the Nigerian Manufacturing Industry.

\section{Guide To Decision.}

This section provides a verification of the hypotheses that were stated earlier using the simple linear regression analysis.

$\mathrm{H}_{01}$ : Production scheduling has no significant influence on cost minimization in Nigerian manufacturing industry.

In testing this hypothesis, operational efficiency as the variable measure for cost minimization of the selected companies was regressed with the percentage responses of the influence of schedule for production activities on productivity performance. The result obtained is presented in the table below; 
Table 4.1: The Influence of Production Scheduling on Cost Minimization

\begin{tabular}{|l|c|}
\hline \multicolumn{1}{|c|}{ Table 4.1: The Influence of Production Scheduling on Cost Minimization } \\
$\qquad$\begin{tabular}{|l|c|}
\hline \multicolumn{1}{|c|}{ Statement Variables } & Values \\
\hline Co-efficient of correlation & 0.539 \\
\hline Co-efficient of determination & 0.288 \\
\hline t-statistic & 4.883 \\
\hline p-value & 0.000 \\
\hline Intercept & 918358.933 \\
\hline Partial Regression Co-efficient & 2142.739 \\
\hline
\end{tabular}
\end{tabular}

Source; SPSS Version 16 Window Output

The table shows an R-value of 0.539 , which suggests a moderate influence of production scheduling on operational efficiency. The co-efficient of determination shows that $28.8 \%$ variation in cost minimization is accounted for by variation in production scheduling hence the model is not a good fit. But since the P-value $(0.000)$ is less than 0.025 for a one-tailed test, it indicates a significant impact. Therefore, the null hypothesis that production scheduling has no significant impact on operational efficiency in the Nigerian manufacturing industry was rejected.

$\mathrm{H}_{02}$ : Production scheduling has no significant influence on equity capital in the Nigerian manufacturing industry.

In testing this hypothesis, equity capital of the selected companies was regressed with the percentage responses of the influence of schedule for production activities on productivity performance. The result obtained is presented in the table below;

Table 4.2: The Influence of Production Scheduling on Equity Capital

\begin{tabular}{|l|c|}
\hline \multicolumn{1}{|c|}{ Statement Variables } & Values \\
\hline Co-efficient of correlation & 0.151 \\
\hline Co-efficient of determination & 0.023 \\
\hline t-statistic & 1.175 \\
\hline p-value & 0.245 \\
\hline Intercept & 1.851 \\
\hline Partial Regression Co-efficient & .003 \\
\hline
\end{tabular}

\section{Source; SPSS Version 16 Window Output}

The table shows an R-value of 0.151 , which suggests a weak influence of production scheduling on equity capital. The co-efficient of determination shows that $2.3 \%$ variation in equity capital is accounted for by variations in production scheduling, hence the model is not a good fit. Therefore, the null hypothesis that production scheduling has no significant impact on equity capital in Nigerian manufacturing industry, was accepted.

$\mathrm{H}_{03}$ : Production scheduling has no significant influence on growth in the Nigerian manufacturing industry.

In testing this hypothesis, net profit before tax as the variable measure for growth of the selected companies was regressed with the percentage responses of the influence of production scheduling on productivity performance. The result obtained is presented in the table below;

Table 4.3: The Influence of Production Scheduling on Growth

Table 4.3: The Influence of Production Scheduling on Growth
\begin{tabular}{|l|c|}
\hline \multicolumn{1}{|c|}{ Statement Variables } & Values \\
\hline Co-efficient of correlation & 0.152 \\
\hline Co-efficient of determination & 0.023 \\
\hline t-statistic & 1.179 \\
\hline p-value & 0.243 \\
\hline Intercept & 47401.119 \\
\hline Partial Regression Co-efficient & 6459.002 \\
\hline
\end{tabular}

\section{Source; SPSS Version 16 Window Output}

The table shows an R-value of 0.152 , which suggests a weak influence of production scheduling on growth. The co-efficient of determination shows that $2.3 \%$ variation in growth is accounted for by variations in production scheduling; hence the model is not a good fit. Therefore, the null hypothesis that production scheduling has no significant influence on growth in the Nigerian manufacturing industry was accepted. 
The following findings were therefore drawn;

1) Scheduling for production activities did not enhance operational efficiency of the firm.

2) Scheduling for production activities did not enhance equity capital of the firm.

3) Scheduling of production activities did not enhance growth of the firm.

\section{Discussion Of Findings}

The logical question one may ask at this point is "what does the research findings entail"? Therefore, this section of the study is focused on a brief discussion of the research findings by relating each of them one after the other to previous studies.

\subsection{Production Scheduling and Cost Minimization}

The key measure of the success of a firm is its productivity performance; hence business executives work assiduously to actualize this objective. One of the major means of doing this is through cost minimization.

In this study, we observed that production scheduling has a moderate impact on both cost minimization and the profitability of manufacturing companies in Nigeria. Only $28.8 \%$ variation in cost minimization is accounted for by variations in production scheduling.

\subsection{Production Planning and enhanced equity capital}

.In this research work, it was gathered that production scheduling has an insignificant influence on equity capital of Nigerian manufacturing firms. Only $2.3 \%$ variations in equity capital is accounted for by variations in the scheduling of production activity. The absence of a significant influence of production scheduling, could be attributed to lack of adequate attention given to production scheduling by production managers.

\subsection{Production Scheduling and Growth.}

With production scheduling, a firm can meet customer requests for delivery times when feasible, meet the present goals for inventory levels, and minimize per unit cost of production. We observed in this study that production scheduling is not a veritable weapon for improved productivity performance in Nigerian manufacturing firms. It was gathered that $2.3 \%$ variation in firm's growth is accounted for by variations in production scheduling.

Production scheduling serves to boost production planning and control. It brings about smooth flow of work throughout the production cycle, prevents conflicts and delays in the use of productive resources and determines the expected time for the arrival of supplies and the shipping of finished products at minimum costs.

In this research work, it was gathered that production scheduling has a moderate influence on operational efficiency but insignificant influence on equity capital and firm's growth of Nigeria manufacturing firms. $28.8 \%$ variations in operational efficiency, $2.3 \%$ variations in equity capital and $2.3 \%$ variations in firm's growth are accounted for by variations in the scheduling of production activity. This is serious. The absence of a significant influence of production scheduling on equity capital and firm's growth, could be attributed to lack of adequate attention given to production scheduling by production managers. Scheduling is not an end in itself but a means to an end. It can boost production planning and control for improved performance if properly utilized.

Our findings in this study offer support to Olarewaju (2010) and Poterba (2006). Olarewaju (2010) affirms that in order to enhance productivity in Nigerian public service, adequate attention must be given to proper work scheduling by public administrators. This is equally applicable to private sector organizations. Also, Poterba (2006), asserted that the end result of undermining work schedule in business organization is inefficient operations, low sales revenue and lack of business growth.

\section{Recommendations}

Based on the findings of this study, the following recommendations were suggested;

1) Since production scheduling did not enhance corporate productivity performance, Nigerian manufacturing firms must with seriousness be involved in the efficient, effective and formal scheduling of all production activities, irrespective of the size and age of the firm.

2) Nigerian manufacturing firms should embrace the application of advanced manufacturing technology, such as automated production technology, computer assisted design and manufacturing (CAD/CAM), robotics and flexible, manufacturing systems.

3) To ensure effective application of advanced manufacturing technology in the Nigerian manufacturing industry, professionals with high technical knowhow should be hired by the organization and effective training programmes, to introduce and master new concepts like lean manufacturing and just-in- time production, should be organized for the organizational members who are to be affected by the technological advancement. 
There should be a formal relationship between the Nigerian manufacturing sector and the tertiary institutions. This will go a long way to make research activities and findings efficient and effective for proper implementation.

\section{References:}

[1]. Abrahamson, F.A. and Pickle, G. (1990) "The Interface of Production and Marketing - An Empirical Analysis"; Journal of Industrial Marketing; 7 (1): 212-236.

[2]. Anwuluorah, M. C. (1987): "Surveys and when is a survey best in Social Research and Information Gathering" in Ugwuegbu, D.C.E. and Onwumere, S. O. (ed) Social Research and Information Gathering, (Lagos, F. G. Printers) p.17 - 27.

[3]. Brayton, G.N. (1983). "Simplified Method of Measuring Productivity Identifies Opportunities for Increasing It". Industrial Engineering. February

[4]. Chase, R. B; Aquilano, J.J; and Jacobs 1;. R. (2001) Operations Management for Competitive Advantage, Boston: McGraw-Hill.

[5]. Chinweizu, C (1979) The West and The Rest of US, London: NOK Publishers

[6]. Craig, C.; Harris, R. (1973). "Total Productivity Measurement at the Firm Level". Sloan Management Review (Spring 1973): 1328.

[7]. Davis, H.S. (2005). Productivity Accounting. University of Pennsylvania.

[8]. Eke, C. (1985) "Why Africa is not Developing West Africa", June, $17^{\text {th }} \mathrm{pp} .1212-1214$

[9]. Eleanya, L. U. M. (2009) De-Industrialization and the Stability of Nation States, Port Harcourt: RIVCAS

[10]. Everette, E.A. (2006) Production and Operations Management - A New Approach; Englewood Cliffs; Prentice-Hall Inc.

[11]. Ezirim, C. B. (2005) Finance Dynamics, principles, techniques and applications, $3^{\text {rd }}$ Edn, Markowitz, Port Harcourt.

[12]. Fowge, F. P. (1997) Modernization without Development in Africa, Africa World Press INC. Asmara, Eritrea.

[13]. Graves, Stephen C. (1999) Manufacturing Planning and Control, Massachusetts Institute of Technology, (November), pp. 17 - 25

[14]. Green, R. (2006) The 33 Strategies of War, New York: Penguin Group

[15]. Higgins, J.M. (2001) Strategic Management and Operations; Chicago; The Diyden $\quad$ Press.

[16]. Ikan, N. (2003) "Impact of Production Control on Corporate Growth"; Decision Science; 27 (4); 616-639.

[17]. Jain K. C.; and L, N. Aggarwal (2008) Production Planning, Control and Industrial Management, Delhi, Nai-Sarak: Khalma Publishers.

[18]. Jaja, S.A. (2005)Small Business Paradigm; Port Harcourt, Pearl Publishers.

[19]. Johnson L. A. and Montgomery, D. C. (2009) Operations Research in Production Planning, Scheduling and Inventory Control, New York: John Wiley.

[20]. Jorgenson, D.V.; Griliches, Z. (1967). "The Explanation of Productivity Change". Review of Economic Studies 34 (99): $249-283$. doi:10.2307/2296675. JSTOR 2296675.

[21]. Kendrick, J.; Creamer, D. (2005). Measuring Company Productivity: A handbook with Case Studies (89). The National Industry Productivity Board.

[22]. Kendrick, J.W. (2004). Improving Company Productivity. The Johns Hopkins University Press.

[23]. Lockyer, K. G. (2009) Factory and Production Management, London Pitman

[24]. Matsushita, K. (2001) "Production Control and Customers' Satisfaction in Industrial Market"; Princeton University Journal of Management; 9 (1): 107-123.

[25]. Mundel, M.E. (1983). Improving Productivity and Effectiveness. Prentice-Hall, Inc.

[26]. Nachimias, C. and Nachimias, D. (1981); Research Methods in the Social Sciences, Alternative Second Edition without Statistics. Edward Anold (Publishers) Ltd. London.

[27]. Nachimias, D. and Nachimias C. (1976): Research Methodology in the Social Science. UK'Edward Arnold.

[28]. Olarenwaju, A.D. (2010) "Productivity Improvement Techniques in the Public Service"; International Journal of Management and Administration; 31(1): 144-159

[29]. Olusegun, D. and Adegbuyi, F.M. (2010) "The Effect of Production Planning and Budgeting on Organizational Productivity"; in Olusegun, D and Adegbuyi, F.M. (Ed.) Production Management - A Strategic Approach; Ibadan; Heinemann Publishers

[30]. Pineda, A. (2009). A Multiple Case Study Research to Determine and respond to Management Information Need Using TotalFactor Productivity Measurement (TFPM). Virginia Polytechnic Institute and State University

[31]. Poterba, D. (2006) "Work Schedule and Business Growth in India Manufacturing Firms"; Administrative Science Quarterly; 21(2): 247-261.

[32]. Susman G.I; and R. Evered R. (1978); “The Scientific Merits of Action Research”. Administrative Science Quarterly. Vol. 123 p 599.

[33]. Umoh G. I. (2005) Quantitative Analysis for Modeling and Decision Making, Nigeria: Lynno Company.

[34]. Vollman, T. E., Berry, W. L. and Why Bark, D.C. (2007) Manufacturing Planning and Control Systems, Boston: McGraw-Hill.

[35]. Weimer, A.M. (1999) Introduction to Business - A Management Approach; Homewood Illinois; Richard D. Irwin.

[36]. Weston, J. F. and Brigham, E. F.(2005) Essentials of Managerial Finance $4^{\text {th }}$ Edn, The Dryden Press,Hinsdale Illinois.

[37]. Wild R. (2008) Production and Operations Management, New York: Holt, Risehart and Winston.

[38]. Winston, W. L. (2004) Operations Research: Applications and Algorithms, California: ITP Wadsworth Inc.

[39]. Winston, W. L. and Albright, S. C. (2007) Practical Management Science: Spread Sheet Modeling and Applications, California: ITP Wadsworth Inc.

Ify Harcourt Wokocha is a Chief Lecturer with the Rivers State College of Arts and Science. He has a PhD in Production and Operations Management from the University of Port Harcourt. His area of specialization includes Operations Management. He is a member of the Nigeria Institute of Management.

G. I. Umoh is an Associate Professor in the University of Port Harcourt. He is presently the Head of Department of Management. He is a member of the Institute of Data Processing London. His areas of Specialization include Operational research applications in business, Advanced Statistics and Statistical analysis, Operations/Production Management, Human factors engineering otherwise known as Ergonomics, Management Information Systems. He is a Fellow, Nigerian Institute of Corporate Administration. He is a Member, Operational Research Society, UK, Member, Institute of Data Processing, London, Member, Ergonomics Society, UK, Member, Institute of Production Engineers, Uk. Member, The Academy of Management Nigeria. 